\title{
Protectionist Trade Policies: A Survey of Theory, Evidence and Rationale
}

\author{
Cletus C. Coughlin, K. Alec Chrystal and Geoffrey E. Wood
}

(3) worldwide during the 1980 s. These pressures are due to vartous economic problems including the large and persistent balance of trade deficits in the United States; the hard times experienced by several industries; and the slow growth of many foreign countries.' proponents of protectionist trade policies argue that international trade has contributed substantially to these problems and that protectionist trade policies will lead to improved results. Professional economists in the United States, however, generally agree that trade restrictions such as tariffs and quotas substantially reduce a nation's economic wellmbeing."

This article surveys the theory, evidence and rationale concerning protectionist trade policies. The first section illustrates the gains from free trade using the concept of comparative advantage. Recent developments in international trade theory that emphasize other reasons for gains from trade are also reviewed. The theoretical discussion is followed by an examination of recent empirical studies that demonstrate the large costs of protectionist trade policies. Then, the rationale for restricting trade is presented. The concluding section summarizes the paper's main arguments.

Cletus $C$. Coughin is a senior economist at the Federal Reserve Bank of St Louis. K. Alec Chrystal is the National Westrninster Bank Professor of Personal Finance at City Umiversity, London. Geoffrev E. Wood is a protessor of economics at City University, London. This article was written while Chrystal was a professor of economics at the University of Sheffield, Sheffield, England. Thomas A. Pollmann provided research assistance.

'See Page (1987) for a detalied examination of trade protectionism since 1974.

${ }^{2}$ This consensus was found in a survey published in the late 1970 s (Kear) et al., 1979). Recent developments in international trade theory, which can be used to justify governmental intervention in trade policy, have not altered the consensus (Krugman. 1987).

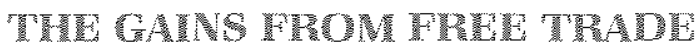

The most famous demonstration of the gains from trade appeared in 1817 in David Ricardo's Principles of Political Economy and Taxation. We use his example involving trade between England and Potugal to demonstrate how both countries can gain from trade. The two countries produce the same two goods, wine and cloth, and the ony production costs are labor costs. The figures below list the amount of labor (e.g." worker-days required in each country to produce one bottle of wine or one bolt of cloth.

\begin{tabular}{lcc} 
& Wine & Cloth \\
\cline { 2 - 3 } & $\frac{3}{7}$ & 7 \\
Portugal & 1 & 5
\end{tabular}

Since both goods are more costly to produce in fingland than in Portugal, England is absolutely less efficient at producing both goods than its prospective trading partner. Portugal has an absolute advantage in both wine and cloth. At first glance, this appears to rule out mutual gains from trade; however, as we demonstrate below, absolute advantage is irrelevant in discerning whether trade can benefit both countries.

The ratio of the production costs for the two goods is different in the two countries. In England, a botlle of wine will exchange for $3 / 7$ of a bolt of cloth because the labor content of the wine is $3 / 7$ of that for cloth. In Portugal, a bottle of wine will exchange for $1 / 5$ of a bolt of cloth. Thus, wine is relatively cheaper in Portugal than in England and conversely, cloth is relatively cheaper in England than in Portugal. The example indicates that Portugal has a comparative advantage in wine production and England has a comparative ad. vantage in cloth production.

The different relative prices provide the basis for 
both countries to gain from international trade. The gains arise from both exchange and specialization.

The gains from exchange can be highlighted in the following manner. If a Portuguese wine producer sells five bottles of wine at home, he receives one bolt of cloth. If he trades in England, he receives more than two bolts of cloth. Hence, he can gain by exporting his wine to England. English cloth-producers are willing to trade in Portugal; for every $3 / 7$ of a bolt of cloth they sell there, they get just over two bottles of wine. The English gain from exporting cloth to land importing wine from Portugal, and the Portuguese gain from exporting wine to land importing cloth from England. Each country gains by exporting the good in which it has a comparative advantage and by importing the good in which it has a comparative disadvantage.

Gains from specialization can be demonstrated in the following manner. Initially, each country is producing some of both goods. Suppose that, as a result of trade, 21 units of labor are shifted from wine to cloth production in England, while, in Portugal, 10 units of labor are shifted from cloth to wine production. This reallocation of labor does not alter the total amount of labor used in the two countries; however, il causes the production changes listed below.

\begin{tabular}{|c|c|c|}
\hline & Bottles of Wine & Bolts of Cloth \\
\hline England & -7 & +3 \\
\hline Portugal & +10 & -2 \\
\hline Net & +3 & +1 \\
\hline
\end{tabular}

The shift of 21 units of labor to the English cloth industry raises cloth production by three bolts, while reducing wine production by seven bottles. In Portugal, the shift of 10 units of labor from cloth to wine rases wine production by 10 bottles, while reducing cloth production by two bolts. This reallocation of labor increases the total production of both goods: wine by three bottles and cloth by one bolt. This increased output will be shared by the two countries. Thus, the consumption of both goods and the wealth of both countries are increased by the specialization brought about by trade based on comparative advantage.

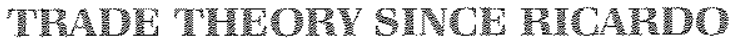

Since 1817 , numerous analyses have generated insights concerning the gains from trade. They chiefly examine the consequences of relaxing the assumptions used in the preceding example. For example, labor was the only resource used to produce the two goods in the example above; yet, labor is really only one of many resources used to produce goods. The example also assumed that the costs of producing additional units of the goods are constant. For example, in England, three units of labor are used to produce one bottle of wine regardless of the level of wine production. In reality, unit production costs could either increase or decrease as more is produced. A third assumption was that the goods are produced in perfectly competitive markets. In other words, an individual firm has no effect on the price of the good that it produces. Some industries, however, are dominated by a small number of firms, each of which can affect the market price of the good by altering its production decision. Some of these extensions are discussed in the appendix

These theoretical developments generally have strengthened the case for an open trading system. They suggest three sources of gains from trade. First, as the market potentially served by firms expands from a national to a world market, there are gains associated with declining per unit production costs. A second source of gains results from the reduction in the monopoly power of domestic firms. Domestic firms, facing more pressure from foreign competitors, are forced to produce the output demanded by consumers at the lowest possible cost. Third is the gain to consumers from incleased product variety and lower prices. Generally speaking, the gains from trade result from the increase in competitive pressures as the domestic economy becomes less insulated from the world economy.

The gains from free trade can also be illustrated graphically. The shaded insert on pages 14 and 15 examines the gains from trade in perfectly competitive markets using supply and demand analysis. The insert also analyzes the effects of trade restrictions, a topic that we discuss below.

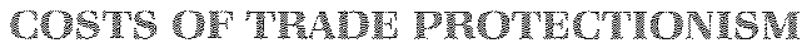

Protectionist trade policies can take numerous forms, some of which are discussed in the shaded insert on pages 16 and 17 . All foms of protection are

\footnotetext{
${ }^{3}$ A profit-maximizing firm produces its output at minimum cost. When firms are insulated from competition, costs are not necessarily being minimized. This situation, which is called $\mathrm{X}$-efficiency, has been stressed by Leibenstein (1980). The increase in competitive pressures due to intemational trade reduces the probability that costs are not minimized.
} 


\section{A Supply and Demand Analysis of the Gains from Free Trade and the Effects of a Tariff}

A standard illustration of the gains from free trade and the effects of a tarif is presented below The analysis assumes perfectly competine mar kets thromghonit

\section{Gains Hrom Hree Trade}

In figue 1 the lines $S$, and 1 , are the US supply and deniand curves for a hyporthetieal good. Iheir intersection at B restits in the equilbrum values for pice and quantity of $P$, and $Q$. Assuming the Whited states has a comparative disadvantage in the produetion of lins good the price will be lower alroad than in the United states let fins lower wolld price be $P_{w}$ and assume that 1 S purehases do not affect this world priee-Graphically this is represented by the horizomal world supply curve S. Ifone allows for free trade, this lower wontd price has two offects Iinst IS Consumers will increase their constmplion to $\mathrm{D}^{\prime}$. Second, US. producers will contrant their production io $S$. The excess of US C consumption over production is US. purchases fron foreign producers (that is, imponts:

The lower price simulaneously benefits is con sumers and hams US prodticers, a faet that wit denlies the recent controversial discussions of I S.

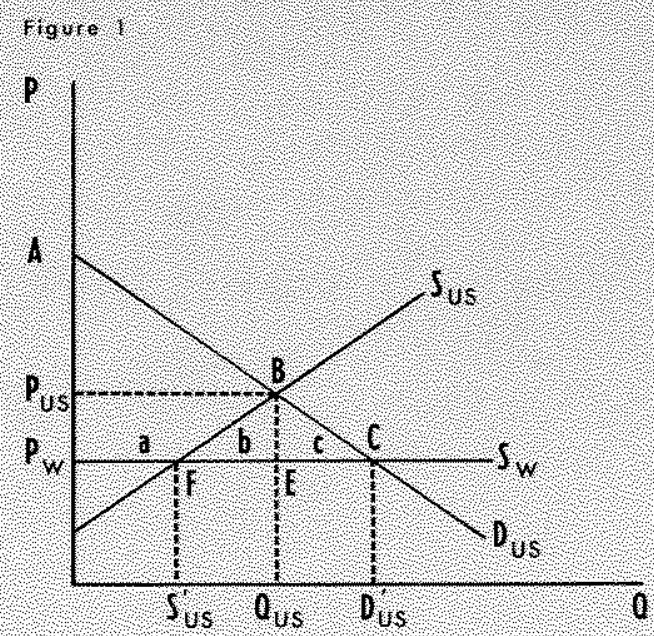

tade poliey the magnitude of these gains and losses using the concepts of constmer and pro. ducer suphlus ean be seen in figure 1 . Consumers gain in two ways linially, consumets purchased Q a a a price per uhit of $P$. With free hade they

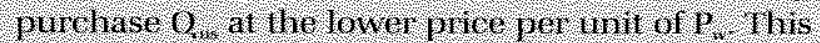
gain is tepresented by the rectangle P. BI $P$. In addition. the lower price induces comsmens to inerease their purchases from $0_{\text {sin }}$ to D'. This gain is represented by the trangle BCl. The tolal gain to constimers is $P$. BC $P$, or ising the lower case letters to represent areas a f it t c. Analogously. producens lose dire to the lower price they tecerve for their butput, S? and dive to their contraction of production from o. to S . The total loss to pro: dueens is ? BH $P$, or a:

The nation as a whole gams hecause the con sumer gains of a + b $+c$ exeeed the proflucer lesses of a by b. I. This analysis can al so be riewed using a good that the Whited states exports. In other works the United states will have a comparative advantage in the production of a good. For the expont good, the change to free trade will cause producer gains that exceed consumer losses.

\section{The Effects of a Tariff}

To make the analysis of proteetionist trade policy as straightforward as possible. The impact of a tariff is analyzed. One ean view any protectionist trade poltcy, however in an analogous mannert for convenience the free trade results in figure 1 are dipl: cated in figure 2 . Given the free trade world price of T. US consumption prodiction and imperts are

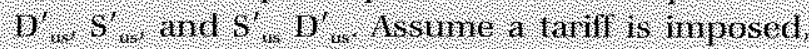
eatsing the price in the I hited States to increase to P. The price in the United states now exceeds price in the world by the amount of the tarif $P$. P

The ligher US price causes consumer purchases to decrease from $\mathrm{O}^{\prime}$, to $\mathrm{D}^{\prime}$. denestic production to inerease from $\mathrm{S}^{t}$. $10 \mathrm{~S}^{t}$, and imponts to decrease fiom $\mathrm{S}^{\prime} \mathrm{B}^{\prime}$, to $\mathrm{S}^{\prime} \mathrm{D}^{\prime}$. By imposing the larif consumens lose the area $P$, I $P$ ? or d t e t i t $\mathrm{g}$ and producers gan the area PIFP or d Do- 


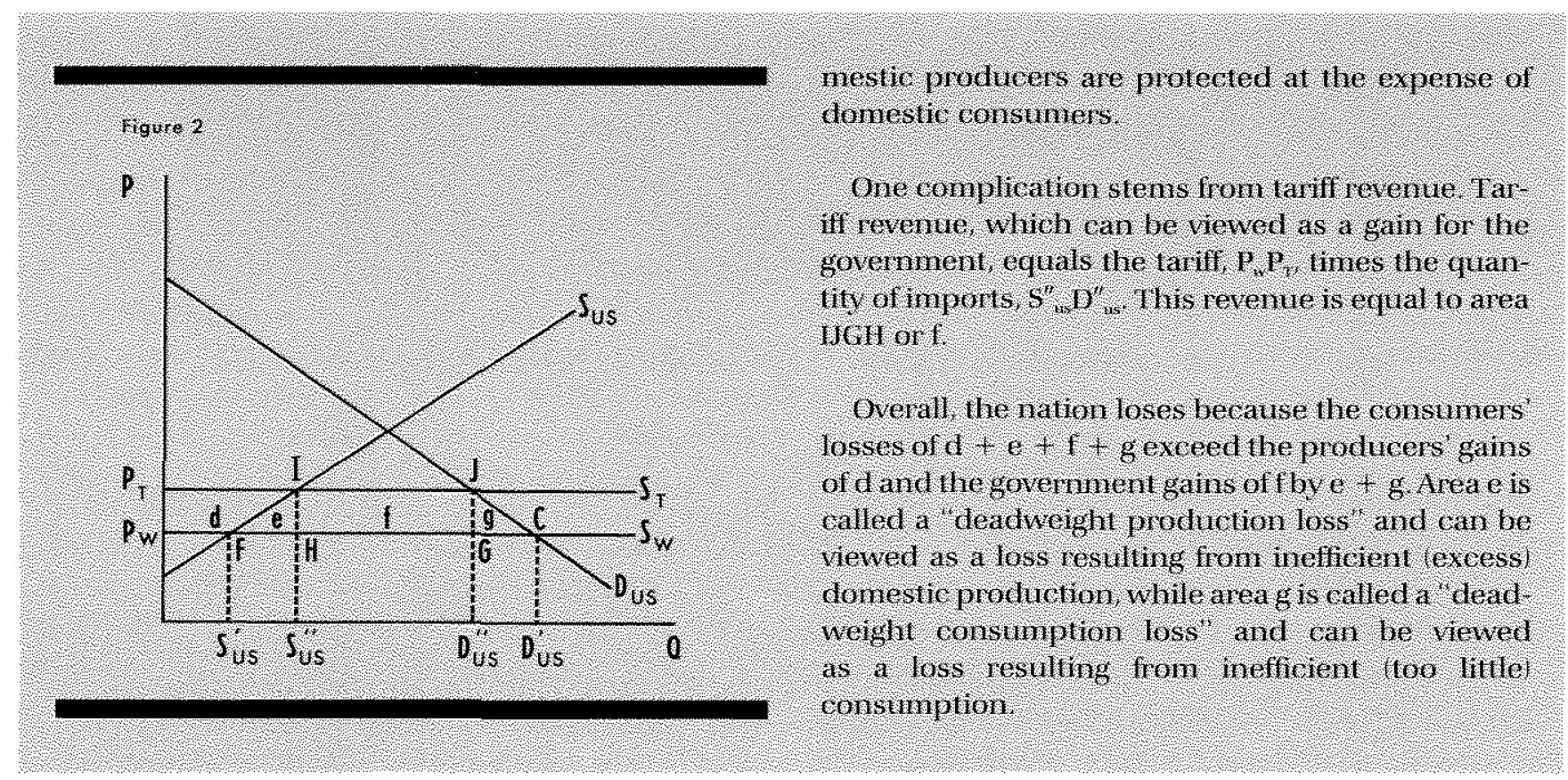

intended to improve the position of domestic relative to foreign producers. This can be done through policies that increase the home market price of the foreign product, decrease the production costs of domestic firms, or somehow restrict the access of foreign producers to the domestic narket.

The specific goal of protectionist trade policies is to expand domestic production in the protected industries, benefting the owners, workers and suppliers of resources to the protected industry. The govermment imposing protectionist trade policies may also benefit, for example, in the form of tariff revenue.

The expansion of domestic production in protected industries is not costless; it requires additional resources from other industries. Consequently, output in other domestic industries is reduced. These industries also might be made less competitive because of higher prices for imported inputs. Since protectionist trade policies frequently increase the price of the protected good domestic consumers are hamed. They lose in two ways. First, their consumption of the protected good is reduced because of the associated rise in its price. Second, they consume less of other goods, as their output dechnes and prices rise.

The preceding discussion highlights the domestic winners and losers due to protectionist trade policies. Domestic producers of the protected good and the government if tarifs are imposed) gan; domestic consumers and other domestic producers lose. Foreign interests are also affected by trade restrictions. The protection of domestic producers will ham some foreign producers; oddly enough, other foreign pro- ducers may beneft. For example, if quotas are placed on imports, some foreign producers may receive higher prices for their exports to the protected market.

There have been numerous studies of the costs of protectionism. We begin by examining three recent studies of protectionism in the United States, then proceed to studies examining developed and, finally, developing countries.

\section{Costs of protectionism in the United States}

Recent studies by Tarr and Morke 1984), Hickok (1985) and Hufbauer et al (1986) estimated the costs of protectionism in the United States. These studies use different estimation procedures, examine different protectionist policies and cover different time periods. Nonetheless, they provide consistent results.

Tarr and Morkre (1984) estimate annual costs to the U.S. economy of $\$ 12.7$ billon 1983 dolar's from all tariffs and from quotas on automobiles, textles, steel and sugar. Their cost estimate is a net measure in which the losses of consumers are offset partially by the gains of domestic producers and the U.S. govermment.

Estimates by Hickok 1985 ) indicate that trade restrictions on only three goods - clothing, sugar, and automobiles - caused increased consumer expenditures of $\$ 1$ billion in 1984 . Hickok also shows that lowincome families are affected more than high-income families. The import restraints on clothing, sugar and automobiles are calculated to be equivalent to a 23 percent income tax surcharge that is, an additional 


\section{Forms Of Protectionism}

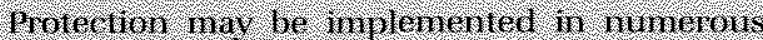

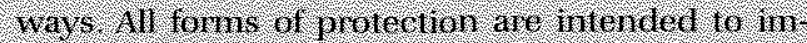

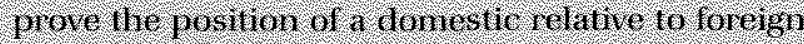

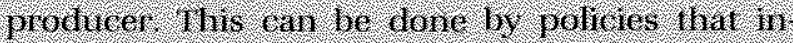
crease he home market prie ol the rogelgh prod

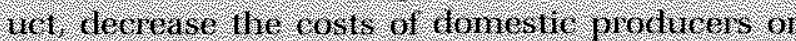

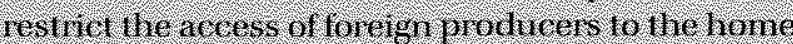
inater in some of her way

\section{Tariffs}

tarifs, whith are simpl, hares inposed un goods

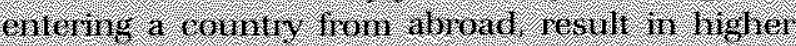

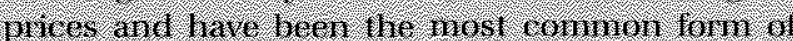

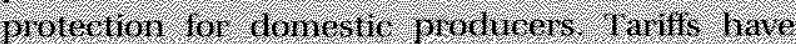

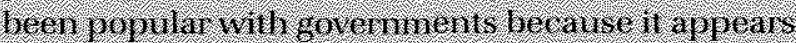

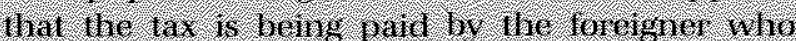

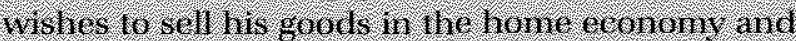

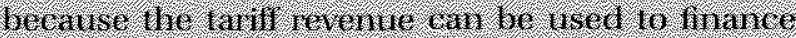

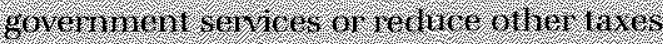

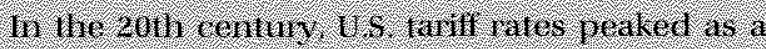

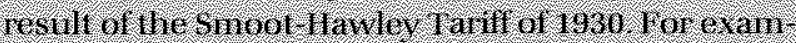

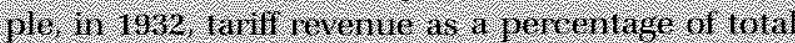

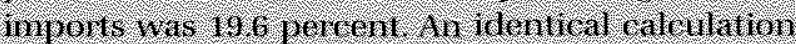

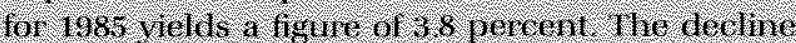

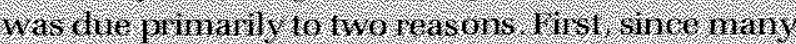

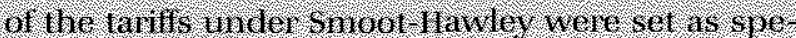

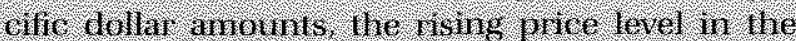

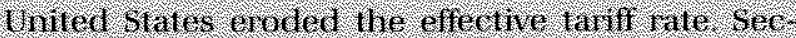

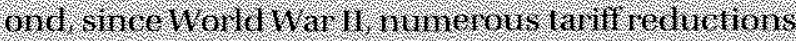

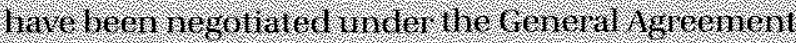

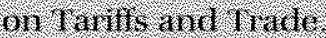

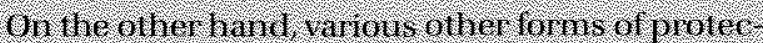

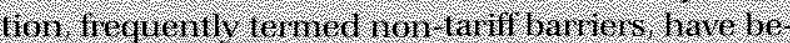

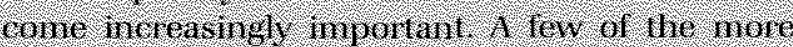

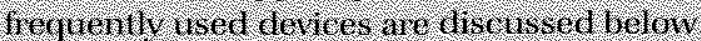

\section{Quotas}

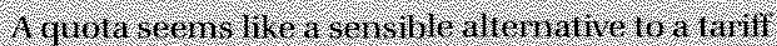

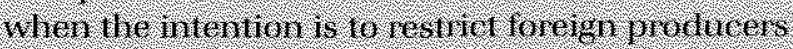

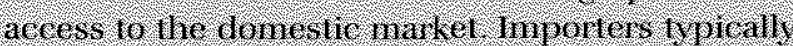

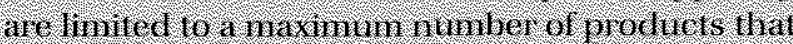

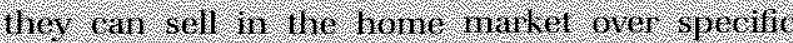

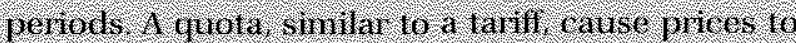

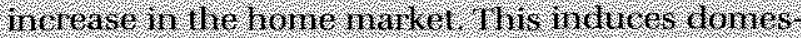

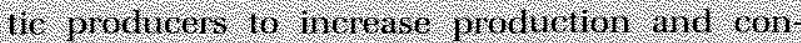

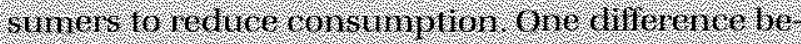

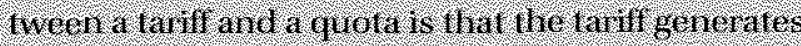

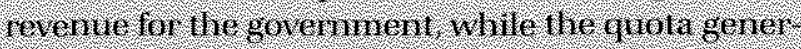
ates a revenue gain 10 he owner of truport herises.

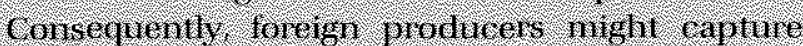

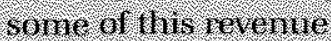

In recent vears, a sighily diflerem velsion ol

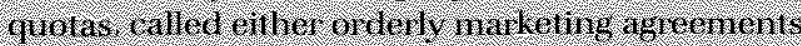

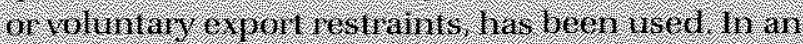

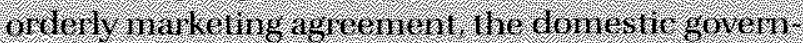

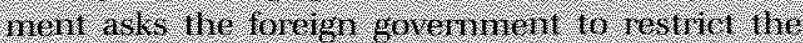

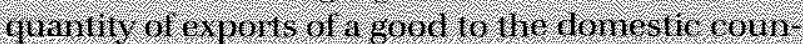

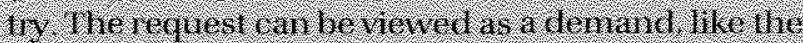

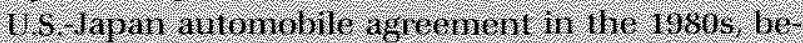

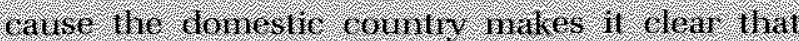

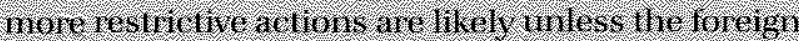

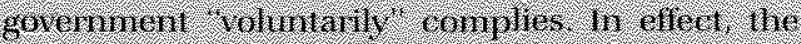

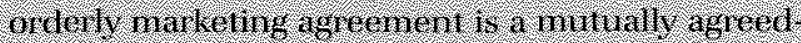
1101111106

\section{Regulatory Bamiers}

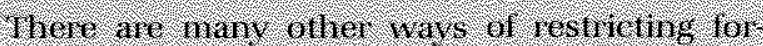

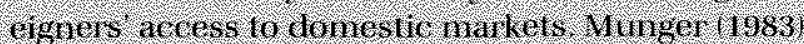

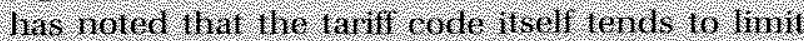

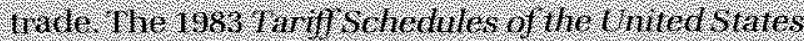

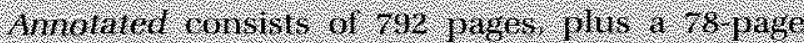

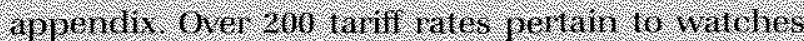

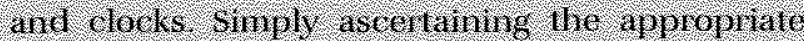

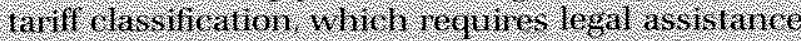

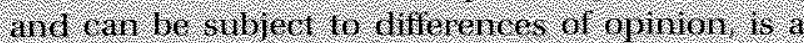
06101017

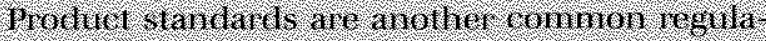

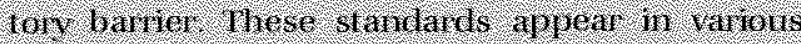

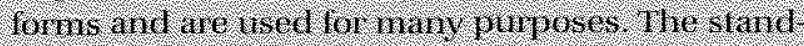

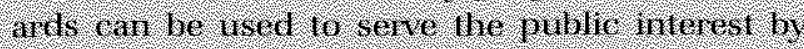

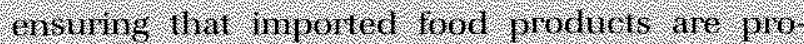

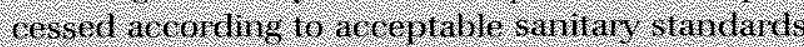

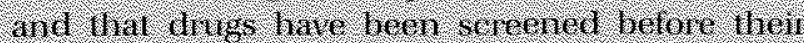

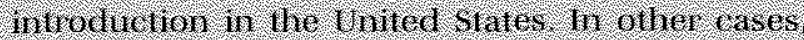

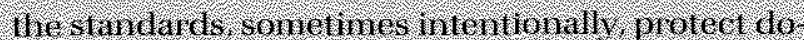

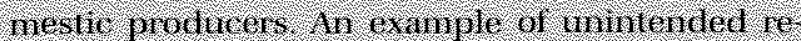


strictions nay be the imposition of salety or polly. fion standarids that were hot prevously bend met by forrign ear:

\section{Subsidies}

An altemalive to testreting the terms inder Which foreigners can eompete in the hone makket is to subsidize domestic producers Subsidies may be focused upon an industry in general or upon the export actinties of the indistry. An example of the fommen, Anseussed by Monct and Megna 1983), is The combination of credit prograns. special fax ineentives and dinect stibsidy payments that beneft lhe Us. shipbulaing indistry An example of the latter is the financial assistane to merease exports proviled by the US Ixport Import Bank through direed loans loan guarintees arid insumance, and discomi loans in eillier case production will expand:

An impoitant difference botween subsidhes and tarifts involves the revenue implicatrons for govern: ment. He former inolves the govemment in pay ing but money, whereas taifs generate ineone for the govemment The effect on domestic preduction and wellare, however, can be the same tuller subsidies as under laviff and quotas in all cases, the protected industry is being subsiaized by the rest of the economy.

\section{Exchange Controls}

All of the alove relate directly to the flow of goods. I fimal lass of restrictions works by restrict ing access to the foreign money required to buy foreign goods. For example, a govermment that wished to proted is exporting and importconnefing industries nay try to hold its exchange rate artificially low. As a restit, foretgn goods would appear expensive in the home market while home goods would ho cheap overseas. Home producers implicilly are subsidized and lome consuneis in plicily are taxed This policy is nomally hard to sustain The centrat bank, in holding the exchange rate down has lo buy loregn exchange with domes. fis eurrency. This hewly issued domestie emrency. incroases the doniestic noney stork and eventually tauses inflation. Inflationary polfcies are not normally regarded as a serisile way of protecting tomestic industry:

There is another aspect to exchange econtiols. The ustificatien is that preventing home residents from investing overseas benefits donestic growth as if leads to greater domestic real inestment in realify it could do exactly the opjosite. Restricting access to foreign assets nay raise the variance and lower the retirn to omanes of domestic wealli. In the short run it atso niay appreciate the domestic: exehange rate and, thereby, nake domestic produeers less competitive. tax added to the normal income tax for families with incomes less than $\$ 10,000$ in 1984 and a 3 percent income tax surcharge for families with incomes exceeding $\$ 60,000$.

Hufbauer et al. (1986) examined 31 cases in which trade volumes exceeded $\$ 100$ million and the United States imposed protectionist trade restrictions.t They generated estimates of the welfare consequences for each major group affected (see table 1). The figures in the table indicate that annual consumer losses exceed $\$ 100$ million in all but six of the cases. The largest losses, $\$ 27$ billion per year, come from protecting the textiles and apparel industry. There also are large

\footnotetext{
${ }^{4}$ While there were cases in which the industry adjusted to its new competitive position and the protection was terminated, these cases were more the exception than the rute. In far more cases, protectionist policies were maintained indefinitely or removed because of favorable demand changes.
}

consumer losses associated with protection in carbon steel ( $\$ 6.8$ billion), automobiles ( $\$ 5.8$ billion) and dairy products ( $\$ 5.5$ billion).

The purpose of protectionism is to protect jobs in specific industries. A useful approach to gain some perspective on consumer losses is to express these losses on a per-job-saved basis. In 18 of the 31 cases, the cost per-job-saved is $\$ 100,000$ or more per year; the consumer losses per-job-saved in benzenoid chemicals, carbon steel (two separate periods), specialty steel, and bolts, nuts and screws exceeded $\$ 500,000$ per year.

Table 1 also reveals that domestic producers were the primary beneficiaries of protectionist policies; however, there are some noteworthy cases where foreign producers realized relatively large gains. For the U.S.-Japanese voluntary export agreement in automobiles, foreign producers gained 38 percent of what domestic consumers lost, while a similar computation 
Table 1

\section{Distribution of Costs and Benefits from Special Protection}

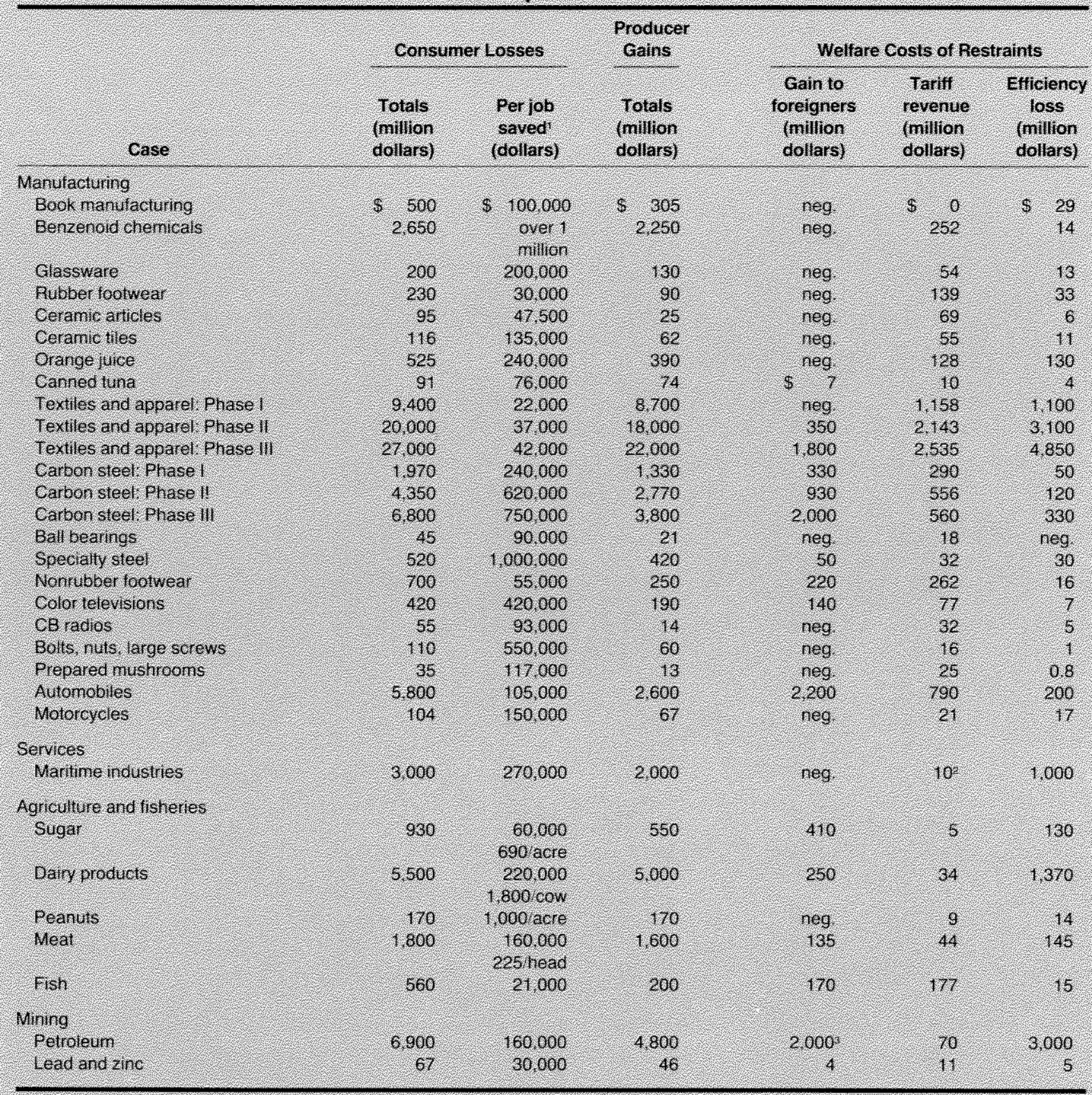

Neg. roglowise

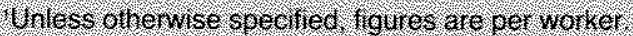

Es stinated duies collected on shib repars perforned abroad

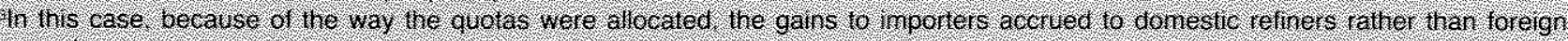
exponters:

soukCE Trade protection in the United States: 3 I Case Stucles. 
for the latest phase of protection for carbon steel was 29 percent.

Finally, table 1 indicates that the efficiency losses are small in comparison to the total losses bome by consumers. These efficiency losses, which are defined precisely and illustrated in the first shaded insert, result from the excess domestic production and the reduction in consumption caused by protectionist trade policies. In lange cases such as textiles and apparel, petroleum, dairy products and the maritime industries, these losses equal or exceed $\$ 1$ billion. It is likely that these estimates understate the actual costs because they do not capture the secondary effects that occur as production and consumption changes in one industry affect other industries." In addition, restrictive trade policies generate additional cosis because of bureaucratic enforcement costs and efforts by the private sector to influence these policies for their own gain as well as simply comply with administrative regulations.

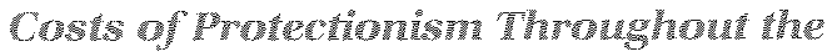 Wromente}

In 1982, the Organization for Economic Cooperation and Development (OECD) began a project to analyze the costs and benefits of protectionist policies in manufacturing in OECD countries. The OECD 11985 highlighted a number of ways that protectionist policies have generated costs far in excess of benefits. Since protectionist policies increase prices, the report conctudes that the attainment of sustained noninflationary growth is hindered by such priceincreasing effects. Moreover, economic growth is potentially reduced if the uncertainty created by varying trade policies depresses investment.

Wood and Mudd (1978), and many others, have shown that imports do not cause higher unemployment. Conversely, the OECD study stresses the fact that a reduction in imports via trade restrictions does not cause greater employment. A reduction in the value of imports results in a similar reduction in the

\footnotetext{
Recent estimates of the costs of protectionist policies using general equitibrium models stgges: that he secondary effects, to the limited extent they are measurabte, are substantial. For exampte, Grais, de Melo and Urata (1986) estimate that the elimination of quotas in Turkey in 1978 would have calsed a 5.4 percent rise in gross domestic product, while Clarete and Whalley (1985) estimate that the elimination of tarifis, quotas and export taxes in the Philippines in 1978 would have caused a 5.2 percent rise in gross national product.
}

value of exports. One rationale for this finding is that a reduction in the purchases of foreign goods reduces foreign incomes and, in turn, causes reduced foreign purchases of domestic goods.

While the reduction in imports increases employment in industries that produce products similar to the previously imported goods, the reduction in exports decreases employment in the export industries. In other words, while some jobs are saved, others are lost; however; this economic reality may not be obvious to businessmen, labor union leaders, politicians and others. Luttrell (1978) has stressed that the jobs saved by protectionist legislation ane more readily observed than the jobs lost due to protectionist legislation. In other words, the jobs that are protected in, say, the textiles industry by U.S. import restrictions on foreign textiles are more readily apparent land publicized than the jobs in agriculture and high technology industries that do not materialize because of the import restrictions. These employment effects will net to approximately zero.

The OECD study also stresses that developing countries need exports to offset their debts. Thus, protectionist trade policies by developed countries affect not only the economic activity of the developing countries, but the stability of the intemational financial system as debtor nations find it increasingly diffcult to service their debts.

Not only does a free trade policy by developed countries benefit developing countries, but a free trade policy by developing countries benefits developing countries. A recent World Bank study (1987) of 41 developing countries compared the performance of countries following a free trade policy with countries following a restricted trade policy. Table 2 lists the

\footnotetext{
Recent evidence shows that protectionist legislation actually may reduce employment. Denzau (1987) estimated that 35,600 manufacturing jobs were lost as a resut of the September 1984 voluntary export restraints that limiled the level of U.S. Steel imports. Despite an increased employment tor producers of steel $(14,000)$ and producers of inputs for steel producers $(2,800)$, these increases were more than offset by the 52,400 job losses by steel-using firms. These losses are due to the higher steel prices that cause steelusing firms to be less competitive in export markets and subject them to more foreign competition in the U.S. market

The World Bank study divides trade strategies into two groups: outward oriented and inward oriented. An outward-oriented strategy, which we call a free trade policy, is one in which trade and industrial policies do not discriminate between production tor the domestic market and exports, nor between purchases of domestic and foreign goods. An inward-oriented strategy, which we call a restricted trade policy, ts one in which trade and industrial policies are biased toward production for the domestic market relative to the export market.
} 


\section{Table 2}

\section{Annual Average Growth of Per Capita Real Gross National Product}

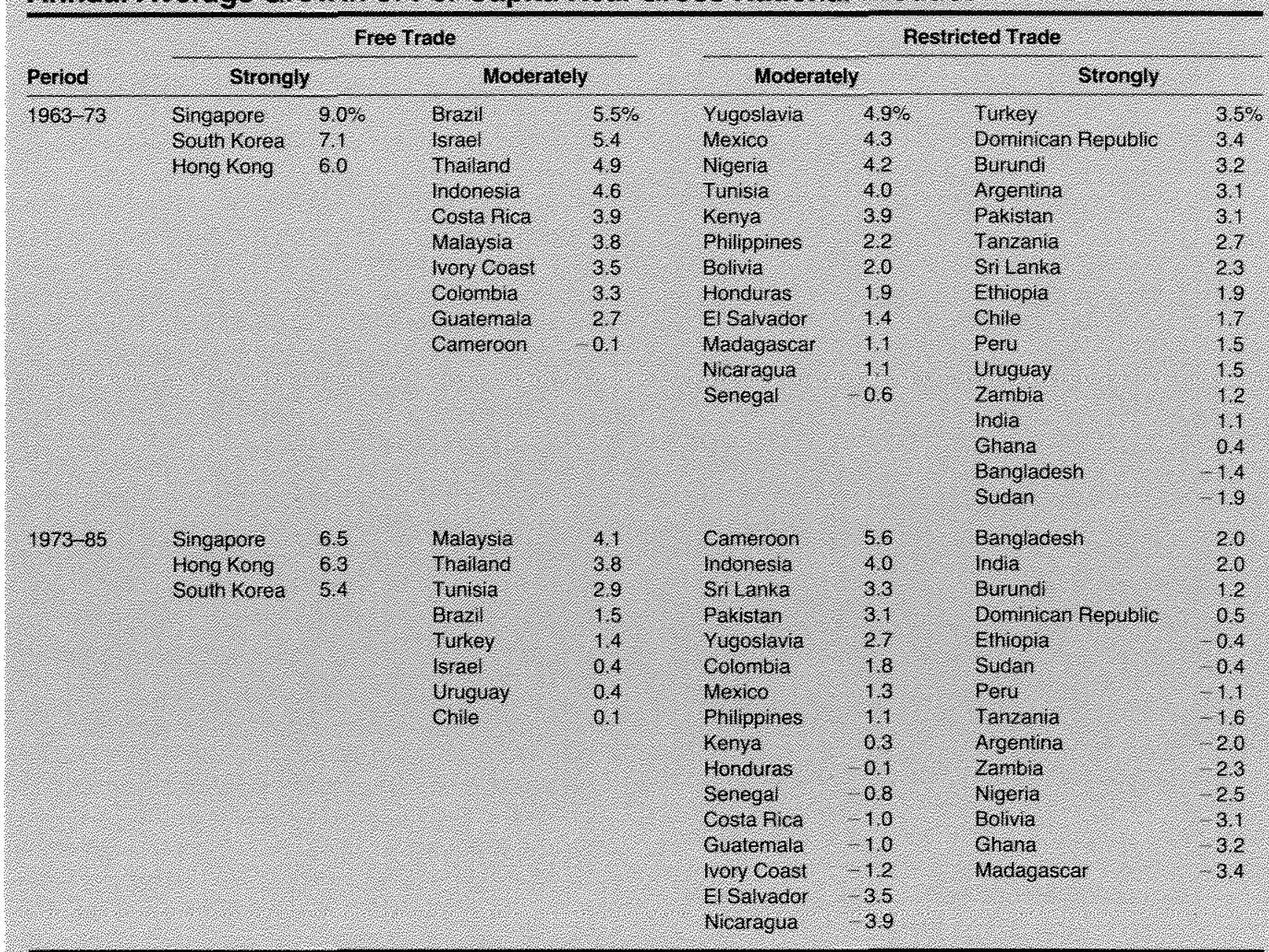

SOURCF World bevelopment Report 1987 and the Economist (1987)

annual average growth in real per capita gross national product for each of the 41 countries for $1963-73$ and 1973-85. Those countries that did not bias industrial production toward the domestic market by trade restrictions grew at faster rates than those that did. For example, the average annual growth rate in real per capita income for $1963-73$ was 6.9 percent in the economies strongly oriented to free trade and 1.6 percent in the economies strongly oriented to restricted trade. For $1973-85$ these growth rates were 5.9 percent and -0.1 percent, respectively.

The study proceeds to identify the macroeconomic reason for the general finding. A given amount of new investment generated more additional output in countries following a free trade policy than a restricted trade policy. The reason is that a free trade environment allows capital to flow to its most highly valued uses, while a restricted trade environment distorts economic incentives.

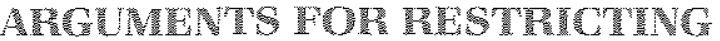

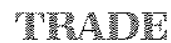

If protectionism is so costly, why is protectionism so pervasive? This section reviews the major arguments 
for restricting trade and provides explanations for the existence of protectionist tade policies.

\section{Nationthefense}

The national defense argument says that import barriers are necessary to ensure the capacity to produce aucial goods in a national emengency. While this argument is especially appealing for weapons during a war, there will likely be demands from other industries that deem themselves essential. For example, the footwear industry will demand protection because military personnel need combat boots.

The national defense argument ignores the possibility of purchases from friendly countries during the emergency. The possibilities of storage and depletion raise additional doubts about the general applicability of the argument. If crucial goods can be stored, for example, the least costly way to prepare for an emergency might be to buy the goods from foreigners at the low world price before an emergency and store them. If the crucial goods are depletable mineral resources, such as oil, then the restriction of oil imports before an emergency will cause a more rapid depletion of domestic reserves. Once again, stockpiling might be a far less costly altemative.

\section{Frcome heristribition}

Since protectionist trade policies affect the distribution of income, a trade restriction might be defended on the grounds that it favors some disadvantaged group. It is unlikely, however, that trade policy is the best tool for dealing with the perceived evils of income inequality, because of its bluntness and adverse effects on the efficient allocation of resources. Attempting 10 equalize incomes directly by tax and transfer payments is likely less costly than using trade policy. In addition, as Hickok's $(1985)$ study indicates, trade restrictions on many items increase rather than decrease income inequality.

\section{Ophimum Thif hrgment}

The optimum tariff argument applies to situations in which a country has the economic power fo alter world prices. This power exists because the country Ior a group of countries acting in consont like the Organization of Petroleum Exporting Countries) is

ssee Pine (1984). such a large producer or consumer of a good that a change in its production or consumption patterns influences world prices. For example, by imposing a tariff, the country can make foreign goods cheaper. Since a tariff reduces the demand for foreign goods, if the tariff-imposing country has some market powet, the world price for the good will fall." The tariffimposing country will gain because the price per unit of its imports will have decheased.

There are a number of obstacles that preclude the widespread application of this argument. Few countries possess the necessary market power and, when they do, only a small number of goods is covered. Secondly, in a world of shifting supply and demand, calculating the optimum tariff and adjusting the rate to changing situations is difficult. Finally, the possibility of foreign retaliation to an act of economic warfare is likely. Such retaliation could leave both countries worse off than they would have been in a free trade environment.

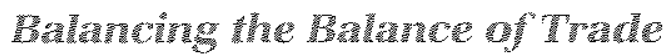

Many countries enact protectionist trade policies in the hope of eliminating a balance of trade deficit or increasing a balance of trade surplus. The destre to increase a balance of trade surplus follows from the mercantilist view that larger trade surpluses are beneficial from a national perspective.

This argument is suspect on a number of grounds. First, there is nothing inherently undesimble about a trade deficit or desirable about a surplus. "For example, faster economic growth in the United States than in the rest of the world would tend to cause a trade deficit. In this case, the trade deficit is a sign of a healthy economy. Second, protectionist policies that reduce imports will cause exports to decrease by a comparable amount. Hence, an attempt to increase exports permanently relative to imports will fail. It is doubtul that the trade deficit will be reduced even temporarily because import quantities do not decline quickly in response to the higher import prices and the revenues of foreign producers might rise.

\footnotetext{
9 II a country such as the United Siates has no market power, the world price is fixed. Consequently, the price faced by U.S. consumers and producers rises by the full amount of the tariff. In the optimum tariff case, the price laced by U.S. consumers and producers rises, but not by the full amoun of the tarift. This must be the case because the world price falls and the amount of the tariff is the difference between the world price and the U.S. price.

see Chrystal and Wood ( 1988 ) earlier in this issue
} 


\section{Protection of Jobs - Pablic Choice}

The protection of jobs argument is closely related to the balance of trade argument. Since a reduction in imports via trade restrictions will result in a similar reduction in exports, the overall employment effects, as found in the OECD $(1985)$ study and many others, are negligible. While the overall effects are negligible, workers land resource owners in specific industries are affected differently.

A domestic industry faced with increased imports from its foreign competition is under pressure to reduce production and lower costs. Productive resources must move from this industry to other domes" tic industries. Workers must change jobs and, in some cases, relocate to other cities. Since this change is forced upon these workers, these workers bear real costs that they are likely to resist. A similar statement can be made about the owners of capital in the affected industry.

Wokkers and other resource owners will likely resist these changes by lobbying for trade restrictions. The previously cited studies on the costs of protectionism demonstrated that trade restrictions entall substantial real costs as well. These costs likely exceed the adjustment costs because the adjustment costs are one-time costs, while the costs of protectionism continue as long as trade restrictions are maintained.

An obvious question is why politicians supply the protectionist legislation demanded by workers and other resource owners. A branch of economics called public choice, which focuses on the interplay between individual preferences and political outcomes, provides an answer. The public choice literature views the politician as an individual who offers voters a bundle of governmentally supplied goods in order to win elections." Many argue that politicians gain by provid" ing protectionist legislation. Even though the national economic costs exceed the benefits, the politician faces different costs and benefits.

Those harmed by a protectionist trade policy for a domestic industry, especially household consumers, will incur a small individual cost that is difficult to identify. For example, a consumer is unlikely to ponder how much extra a shirt costs because of protectionist legislation for the textiles and apparel industry.

\footnotetext{
"The role of pressure groups, acting in their economic self-interest, has been stressed by Stigler (1971) and Peltzman (1976). For references, as well as an example of an international trace study focused on the interacton of politicians and interest groups, see Coughlin (1985).
}

Even though the aggregate effect is large, the harm to each consumer may be small. This small cost, of which an individual may not even be aware, and the costs of organzing consumers deter the fomation of a lobby against the legislation.

On the other hand, workers and other resource owners are very concerned about protectionist legislation for their industry. Their benefits tend to be large individually and easy to identify. Their voting and campaign contributions assist politicians who support their postions and penalize those who do not. Thus, politicians are likely to respond to their demands for protectionist legislation."2

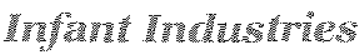

The preceding argument is couched in terms of protecting a domestic industry. A slightly diferent argument, the so-called infant industry case, is couched in terms of promoting a domestic industry. Suppose an industry, already established in other countries, is being established in a specific country. The country might not be able to realize its comparative advantage in this industry because of the existing cost and other advantages of foreign firms. Initially, owners of the fledgling firm must be willing to suffer losses until the firm develops its market and lowers its production costs to the level of its foreign rivals. In order to assist this entrant, tariff protection can be used to shield the firm from some foreign competition.

After this temporary period of protection, free trade should be restored; however, the removal of tariff protection frequently is resisted. As the industry develops, its political power to thwart opposing legislation also increases.

Another problem with the infant industry argument is that a taliff is not the best way to intervene. A production subsidy is superior to a tariff if the goal is to expand production. $A$ subsidy will do this directly, while a tariff has the undesimable side effect of reducing consumption.

In many cases, intervention might not be appropriate at all. If the infent industry is a good candidate for being competitive internationally, borrowing from the

\footnotetext{
${ }^{12}$ Special interests benefiting trom trade will likely resist the forces for protectionist legislation. Destler and Odell ( 1987 ) identify exporters, industrial import users, retailers of imported products, businesses providing trade-related services, foreign exporters, and foreign governments as interest groups capable of exerting some antiprotection pressure. Decisions about protectionist legislation restlt from the interaction of both prowprotection and anti-protection forces.
} 
private capital markets can finance the expansion. Investors are willing to absorb losses temporarily if the prospects for future profits are sufficiently good.

\section{Spillover Efecis}

The justification for protecting an industry, infant or otherwise, frequently entails a suggestion that the industry generates spillover benefits for other industries or individuals for which the industry is not compensaled. Despite patent laws, one common suggestion is that certain industries are not fully compensated for their research and development expenditures. This argument is trequently directed toward technologically progressive industries where some firms can capture the results of other firms' research and development simply by dismantling a product to see how it works.

The application of this argument, however, engenders a number of problems. Spillovers of knowledge are difficult to measure. Since spillovers are not market transactions, they do not leave an obvious trail to identify their beneficiaries. The lack of market transactions also complicates an assessment of the value of these spillovers. To determine the appropriate subsidy, one must be able to place a dollar value on the spillovers generated by a given research and development expenditure. Actually, the calculation requires much more than the already difficult task of reconstructing the past. It requires complex estimates of the spillovers' future worth as well. Since resources are moved from other industries to the targeted industry, the government must understand the functioning of the entire economy.

Finally, there are political problems. An aggressive application of this argument might lead to retaliation and a mutually destructive trade war. In addition, as interest groups compete for the governmental assistance, there is no guarantee that the right groups will be assisted or that they will use the assistance efficiently.

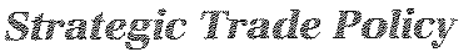

Recent theoretical developments have identified cases in which so-called strategic trade policy is superior to free trade. As we discussed earlier, decreasing unit production costs and market structures that contain monopoly elements are common in industries involved in international trade. Market imperfections immediately suggest the potential benefits of governmental intervention. In the strategic trade policy argument, government policy can alter the terms of com- petition to favor domestic over foreign firms and shift the excess returns in monopolistic markets from foreign to domestic firms.

Krugman (1987) illustrates an example of the argument. Assume that there is only one firm in the United States, Boeing, and one multinational firm in Europe, Airbus, capable of producing a 150-seat passenger aircraft. Assume also that the aircraft is produced only for export, so that the returns to the firm can be identified with the national interest. This export market is profitable for either firm if it is the only producer; however, it is unprofitable for both firms to produce the plane. Finally, assume the following payoffs are associated with the four combinations of production: 1) if both Boeing and Airbus produce the aircraft, each firm loses $\$ 5$ million; 2) if neither Boeing nor Airbus produces the aircraft, profits are zero; 3) if Boeing produces the aircraft and Airbus does not Boeing profits by $\$ 100$ million and Airbus has zero profits; and 4) if Airbus produces the aircraft and Boeing does not, Airbus profits by $\$ 100$ million and Boeing has zero profits.

Which firm(s) will produce the aircraft? 'The exam" ple does not yield a unique outcome. A unique outcome can be generated if one firm, say Boeing, has a head start and begins production before Airbus. In this case, Boeing will reap profits of $\$ 100$ million and will have deterted Airbus from entering the market because Airbus will lose $\$ 5$ million if it enters after Boeing.

Strategic trade policy, however, suggests that judicious governmental intervention can alter the outcome. If the European governments agree to subsidize Airbus' production with $\$ 10$ million no matter what Boeing does, then Airbus will produce the plane. Production by Airbus will yield more profits than not producing, no matter what Boeing does. At the same time, Boeing will be detered from producing because it would lose money. Thus, Airbus will capture the entire market and reap profits of $\$ 110$ million, $\$ 100$ million of which can be viewed as a transfer of profits from the United States.

The criticisms of a strategic trade policy are similar to the criticisms against protecting a technologically progressive industry that generates spillover benefits. ${ }^{13}$ There are major informational problems in applying a

\footnotetext{
33A recent volume edited by Paul Krugman (1986) examines the policy implications of the new trade literature. See Grossman's article in that volume for a discussion of the information requirements.
} 
strategic trade policy. "The government must estimate the potential payoff of each course of action. Economic knowledge about the behavior of industries that have monopoly elements is limited. Firms may behave competitively or cooperatively and may compete by setting prices or output. The behaviof of rival governments also must be anticipated, Foreign retaliation must be viewed as likely where substantial profits are at stake. In addition, many interest groups will compete for the governmental assistance. Though only a small number of sectors can be considered potentially strategic, many industries will make a case for assistance.

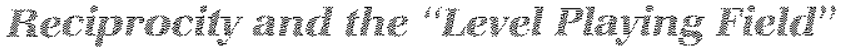

Bhagwati and Irwin (1987) note that U.S. trade policy discussions in recent years have frequently stressed the importance of "fair trade." The concept of fair trade, which is technically referred to as reciprocity, means different things to different people.

Under the General Agreement on Tariffs and Trade, negotiations to reduce trade barriers focus upon matching concessions. This form of reciprocity, known as first-difference reciprocity, attempts to reduce trade barriers by requiring a country to provide a tariff reduction of value comparable to one provided by the other country. In this case, reciprocity is defined in terms of matching changes.

Recent U.S. demands, exemplified by the Gephardt amendment to the current trade legislation, reveal an approach that is called full reciprocity. This approach seeks reciprocity in terms of the level of protection bilaterally and over a specific range of goods. Reciprocity requires equal access and this access can be determined by bilateral trade balances. A trade deficit with a trading partner is claimed to be prima facie evidence of unequal access. Examples abound. For example. U.S. construction firms have not had a major contract in Japan since 1965, while Japanese construction firms did $\$ 1.8$ billion worth of business in the United States in 1985 alone. Recent legislation bars Japanese participation in U.S. public works projects until the Japanese offer reciprocal privileges.

As the name suggests, the fundamental argument for fair trade is one of equity. Domestic producers in a free trade country argue that foreign trade barriers are unfair because it places them at a competitive disadvantage. In an extreme version, it is asserted that this unfair competition will virtually eliminate U.S. manufacturing, leaving only jobs that consist primarily of flipping hamburgers at fast food restaurants or, as Bhagwati and Irwin have said, rolling rice cakes at Japanese-owned sushi bars. While domestic pro- ducers are relatively disadvantaged, the wisdom of a protectionist response is doubtful. Again, the costs of protectionism exceed substantially the benefits from a national perspective.

In an attempt to reinforce the argument for fair trade, proponents also argue that retaliatory threats, combined with changes in tariffs and non-tariff barriers, allow for the simultaneous protection of domestic industries against unequal competition and induce more open foreign markets. This more flexible approach is viewed as superior to a "one-sided" free trade policy. The suggestion that a fair trade policy produces a trading environment with fewer trade restrictions allows proponents to assert that such a policy serves to promote both equity and efficiency. In other words, not only will domestic and foreign producers in the same industry be treated equally, but the gains associated with a freer trading environment will be realized.

On the other hand, critics of a fair trade policy argue that such a policy is simply disguised protectionism - it simply achieves the goals of specific interest groups at the expense of the nation at large. In many cases, fair traders focus on a specific practice that can be portrayed as protectionist while ignoring the entire package of policies that are affecting a nation's competitive position. In these cases, the foreign country is more likely either not to respond or retaliate by increasing rather than reducing their trade barriers. In the latter case, the escalation of trade barriers causes losses for both nations, which is exactly opposite to the alleged effects of an activist fair trade policy.

Critics of fair trade proposals are especially bothered by the use of bilateral trade deficits as evidence of unfair trade. In a world of many trading countries, the trade between two countries need not be balanced for the trade of each to be in global balance. Differing demands and productive capabilities across countries will cause a specific country to have trade deficits with some countries and surpluses with other countries. These bilateral imbalances are a normal result of countries trading on the basis of comparative advantage." Thus, the focus on the bilateral trade defieit can produce inappropriate conclusions about fairness and, more importantly, policies attempting to eliminate bilateral trade deficits are likely to be very costly because they eliminate the gains from a multilateral trading system.

\footnotetext{
${ }^{14}$ Bergsten and Cline (1985) estimate an equilibrium U.S. -Japanese
} bilateral trade deficit of $\$ 20-\$ 25$ billion annually. 


\section{CONCWUSWN}

The proliferation of protectionist trade policies in recent years provides an impetus to reconsider their worth. In the word of traditional trade theory, characterized by perfect competition, a defnitive recommendation in favor of free trade can be made. The gains from international trade result from a reallocam tion of productive resources toward goods that can be produced less costly at home than abroad and the exchange of some of these goods for goods that can be produced at less cost abroad than at home.

Recent developments in intemational trade theory have examined the consequences of international trade in makkets where there are market imperfections, such as monopoly and technological spillovers. Do these imperfections justify protectionist trade policies? The answer continues to be no. While protectionist trade policies may offset monopoly power overseas or advantageously use domestic monopoly power, trade restrictions tend to reduce the competition faced by domestic producers, protecting domestic producers at the expense of domestic consumers.

The empirical evidence is clear-cut. The costs of protectionist trade policies far exceed the benefts. The losses suffered by consumers exceed the gains reaped by domestic producers and government. Low income consumers are relatively more adversely affected than high-income consumers. Not ony are there inefficiencies associated with excessive domestic production and restricted consumption, but there are costs associated with the enforcement of the pro tectionist legislation and attempts to influence trade policy.

The primary reason for these costly protectionist policies relies on a public choice argument. The desire to influence trade policy arises from the fact that trade policy changes benefit some groups, while harming others. Consumers are harmed by protectionist legislation; however, ignorance, small individual costs, and the high costs of organizing consumers prevent the consumers from being an effective force. On the other hand, workers and other resource owners in an industry are mote likely to be effective politically because of their relative ease of organizing and their individually large and easy-to-identify benefts. Politicians interested in re-election will most likely respond to the demands for protectionist legislation of such an interest group.

The empirical evidence also suggests that the adverse consumer effects of protectionist trade policies are not short-lived. These policies generate lower economic growth rates than the rates associated with free trade policies. In tum, slow growth contributes to additional protectionist pressures.
Interest group pressures from industries experiencing difficulty and the general appeal of a "level plaving field" combine to make the reduction of trade barriers especially difficult at the present time in the United States. Nonetheless, nationa interests will be served best by such an admittedly difficult political course. In light of the current Uruguay Round negotiations un der the General Agreement on Tariffs and Trade, as well as numerous bilateral discussions, this fact is especially timely.

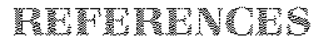

Bergsten, C. Fred, and William R. Cline. The United States-Japan Economic Problem (Institute for International Economics, October 1985).

Bhagwati, Jagdish N., and Douglas A. Irwin. "The Return of the Reciprocitarians - U.S. Trade Policy Today," World Economy (June 1987), pp. 109-30.

Brander, James A. "Intra-Industry Trade in Identical Commodities," Joumal of International Economics (February 1981), pp. 1-14.

Brander, James A., and Paul R. Krugman. "A 'Reciprocal Dumping Model of International Trade, "Journal of International Economics (November 1983), pp. 313-21.

Chrystal, K. Aleo, and Geoffrey E. Wood. "Are Trade Deficits a Problem?" this Review (January/February 1988), pp. 5-13.

Clarete, Ramon L, and John Whalley. "Interactions Between Trade Policies and Domestic Distortions," Center for the Study of International Economic Relations Working Paper $8522 \mathrm{C}$ (London, On tario: University of Western Ontario, 1985).

Coughlin, Cletus C. "Domestic Content Legislation: House Voting and the Economic Theory of Regulation," Economic Inquiry (July 1985), pp. $437-48$.

Denzau, Arthur T. "How Import Restraints Reduce Employment," Washington University Center for the Study of American Business, Formal Publication \#80 (June 1987).

Destler, I. M., and John S. Odell. Anti-Protection: Changing Forces in United States Trade Politics (institute for International Economics, 1987).

Dixit, Avinash $\mathrm{K}_{\text {., }}$ and Victor D. Norman. Theory of international Trade (Cambridge University Press, 1980).

Dixit, Avinash K., and Joseph E. Stiglitz. "Monopolistic Competition and Optimum Product Diversity," American Economic Review (June 1977), pp. 297-308.

The Economist. July 4, 1987, p.74.

Grais, Wafik, Jaime de Melo, and Shujiro Urata. "A General Equilibrium Estimation of the Effects of Reductions in Tariffs and Quantitative Restrictions in Turkey in 1978," in T. N. Srinivasan and John Whaliey, eds. General Equilibrium Trade Policy Modeling (MIT Press, 1986).

Grossman, Gene M. "Strategic Export Promotion: A Critique," Stra. tegic Trade Policy and the New Intemational Economics in Paul R Krugman, ed. (MIT Press, 1986), pp. 47-68.

Helpman, Ethanan. "International Trade in the Presence of Product Differentiation, Economies of Scale and Monopolistic Competition," Joumal of Intemational Economics (August 1981), pp. 30540.

Hickok, Susan. "The Consumer Cost of U.S. Trade Restraints," Federal Reserve Bank of New York Quarterly Review (Summer 1985), pp. 1-12. 
Hufbauer, Gary Clyde, Diane T. Berliner, and Kimberly Ann Elliott. Trade Protection in the United States: 31 Case Studies (Institute for International Economics, 1986).

Keatl, James R., Clayne L. Pope, Gordon C. Whiting, and Larry T. Wimmer. "A Confusion of Economists?" American Economic Review, Papers and Proceedings (May 1979), pp. 28-37.

Kierzkowski, Henry K. "Recent Advances in Intemational Trade Theory: A Selective Survey," Oxford Review of Economic Policy (Spring 1987), pp. 1-19.

Krugman, Paul R. "Is Free Trade Passé?" Journal of Economic Perspectives (Fall 1987), pp. 131-44.

Strategic Trade Policy and the New International Economics (MIT Press, 1986).

Lancaster, Kelvin. " Intra-Industry Trade Under Peffect Monopoistic Competition," Joumal of International Economics (May 1980), pp. $151-75$. Press, 1979)

Variety, Equity, and Efficiency (Columbia University

Leibenstein, Harvey. Beyond Economic Man (Harvard University Press, 1980).

Luttrell, Clifton B. "Imports and Jobs - The Observed and the Unobserved," this Review (June 1978), pp. 2-10.

Mill, John Stuart. Principles of Political Economy, W. J. Ashley, ed. (Longman, 1909).

Morici, Peter, and Laura L. Megna, U.S. Economic Policies Affecting Industrial Trade: A Quantitative Assessment (National Planning Association, 1983).

Munger, Michael C. "The Costs of Protectionism: Estimates of the Hidden Tax of Trade Restraint, " Washington University Center for the Study of American Business, Working Paper \#80 (July 1983).

Organization for Economic Co-Operation and Development (OECD). Costs and Benefits of Protection (1985).

Page, Sheila. "The Rise in Protection Since 1974," Oxford Review of Economic Policy (Spring 1987), pp. 37-51.

Pelizman, Sam. "Toward a More General Theory of Regulation," Journal of Law and Economics (August 1976), pp. 211-40.

Pine, Art. 'Footwear Indusiry Tells Congress 'Shoe Gap' Threatens U.S. Defense," Wall Street Journal, August 24, 1984.

Aicardo, David. The Principles of Poltical Economy and Taxation (Penguin, 1971).

Stigler, George J. "The Theory of Economic Regulation," Bell Journal of Economics and Management Science (Spring 1971), pp. 3 21.

Stolper, Wolfgang, and Paul A. Samuelson. "Protection and Real Wages," Review of Economic Studies (November 1941), pp. 58 73.

Tarr, David G, and Morris E. Morkre. Aggregate Costs to the United States of Tarifts and Quotas on imports: General Tariff Cuts and Removal of Quotas on Automobiles, Steel, Sugar, and Textiles, Bureau of Economics Stafl Report to the Federal Trade Commission (December 1984).

Venabies, Anthony, and Alasdair Smith. "Trade and Industrial Policy Under Imperfect Competition," Economic Policy (October 1986), pp. $621-72$.

Wood, Geoffrey E., and Douglas R. Mudd. "The Recent U.S. Trade Deficit - No Cause for Panic," this Review (April 1978), pp. 2-7.

World Bank. World Development Report 1987 (Oxford University Press, 1987). 


\section{Appendix Developments in International Trade Theory and the Gains from Trade}

Since 1817, numerous developments have taken place in international trade theory. The consequences of more than one factor of production, increasing and decreasing unit production costs, and imperfectly competitive markets are examined in this appendix. Special attention is focused on developments in international trade theory in the last decade.

\section{InCPRSing Promenthenton}

Assume that, in the United States, two resources, labor and capital (e.g, machines), are used in the production of two goods, automobiles and airplanes. The prices of these resources will be affected differently by trade. As trade develops, demand for the exported good Ithat is, the good in which the United States has a comparative advantage will increase and demand for U.S. production of the imported good will fall. This demand shift causes the price of the exported good to rise relative to the price of the imported good. Similarly, the shift may also produce changes in the prices of resources: however, these price changes are not always obvious.

Initially, assume that the resources cannot be transferred across industries. For example, the labor and capital used to produce automobiles, the good imported into the United States, cannot be used to produce airplanes, the exported good. Consequently, as the price of airplanes rises in the United States, the compensation for labor and capital in the aiplane industry will rise; meanwhile, the decline in autornobile prices causes a decline in compensation for labor and captal in the industry. It would not be strprising if labor and owners of capital in the industry would resist such changes by asking for trade protection.
While resomices may not be easily transferred across industries in the short run, workers can change jobs and capital can be moved as time passes. If resources are mobile, then the longer-run consequences for labor and owners of capital are different from those described above. Even if labor and capital are perfectly mobile, however, one set of resource owners may benefit while another group is harmed by trade.'

The real world is more complicated than this discussion has allowed. There are more than two factors of production and varying degrees of mobility for these factors. For example, the U.S. labor force contains scientists and engineers as well as short-order cooks. Nonetheless, the underlying analysis does suggest some generalizations. When trade oceurs, owners of the resources that are more specialized in the production of export goods will tend to become weal-

\footnotetext{
tWho wins and who loses? If depends on the U.S. endowment of capital to labor relative to other countries. If the United States has relatively larger amounts of capital to labor relative to other countries, then owners of captal would benefit, while labor would be harmed. This result follows from the Stolper-Samuelson Theorem (Siofper and Samuelson, 1941). In the example, the United States is defined to be captal-abundant. The example also implicity assumes that airplanes are produced by capial-intensive methods and automobiles by labor-intensive methods. Thus, the production of airplanes requires the use of more capital relative to labor than automobiles. Since the United States is relatively well-endowed with capital and the production of airplanes is capital intensive, the United States will have a comparative advantage in the production of airplanes. With the elimination of trade barriers, the relative price of airplanes to automobiles will increase. The Stolper-Samuelson Theorem shows that an increase in the relative price of the capital intensive good witn increase the retum to capital relative to the prices of both goods and reduce the return to labor relative to the prices of both goods.
} 
thier; those who own resources more specialized in the production of import-competing goods will tend to lose wealth. people also gain or lose, however, depending on what happens to the prices of the goods they buy. Individuals who chefly consume imported goods will benefit, while those who prefer consuming the expotted goods will lose. Thus, the net effect on any individual depends on both the gains or losses associated with the price changes on the goods that he consumes and the effect of trade on his weath for incomel.

\section{Tucressing Unit Poduction Cosis}

A second assumption underlying the Ricardian example of the gains from trade is that unt production costs are constant. If unit production costs rise as more is produced, however, the general conclusions about the gains from trade remain essentially unchanged. The major difference is that rising unit production costs limit the extent to which specialization occurs.

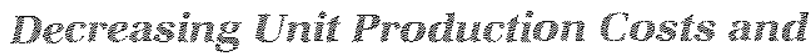 Inperifech Comperition}

On the other hand, if unit production costs decrease as production increases, the extent to which actual trade patterns can be explained by comparative advantage becomes unclear. It also forces trade theory to deal with numerous characteristics of international trade in the real world. The market structure of indus tries engaged in trade is frequently highly concentrated. In other words, the individual firms in an industry, contrary to those in a perfectly competitive industry, can affect the market price of their good by their production and advertising decisions. In addifion, trade statistics show that intra-industry trade (i.e., the simultaneous export and import of the output of the same industry) accounts for increasingly larger shares of world trade.

In the last decade, trade theorists have developed numerous models to deal with these facts. An exhaustive review of this rapidly expanding literature is beyond the scope of this appendix; however, a few illustrative articles are discussed in order to establish some key points. Brander (1981) and Brander and Krugman (1983) developed models using a homogeneous good to highlight how imperfect competition can cause intra-industry trade and how intra-industry trade can arise in the absence of cost differences.

Assume two countries with one firm in each country. The firms are producing a homogeneous good under identical cost situations and there are no trans- portation costs. Each firm operates under what is termed a "Cournot conjecture," meaning that each firm assumes its production decision will not affect its rival's production decision. Before international trade, each firm has a monopoly position in its home market. Allowing for free trade induces each firm to enter the other firm's market, because price exceeds marginal cost in each country. Thus, the same good will flow to and from each country.

Kierzkowski (1987) has noted that the bulk of intraindustry trade involves differentiated rather than homogeneous goods. Two appoaches, Lancaster's (1979) characteristics approach and Dixit and Stiglitz's (1977) "love of variety" approach, have provided the foundation for trade models involving differentiated goods.

In the characteristics approach, individuals have preferences for the characteristics of goods rather than for collections of the goods themselves. A group of goods is defined as goods possessing the same characteristics but in different proportions. A diversity in consumer preferences causes different consumers to prefer different products (i.e., varieties) of a group of goods.

Helpman (1981) and Lancaster (1980) used the characteristics approach to show how intra-industry trade results from combining the demand for variety with economies of scale. The change from autarchy to free trade enlarges the market and causes output of the existing varieties to increase and the production of new varieties to begin. Consumers gain from the production of more varieties and lower prices as economies of scale are realized.

The sources of gains from trade are identical using the love-of-variety and characteristics approaches. In the love of -variety approach, which is used by Dixit and Nomman (1980), consumers have identical tastes and prefer to consume as many types of the differentiated product as possible.

The introduction of imperfect competition and declining unit production costs suggest three sources of gain from free trade. As the market potentially served by firms expands from a national to a world market there will be gains due to declining unit production costs. The second is the reduction in monopoly power of firms faced with foreign competitors. The third is the gain to consumers from lower prices and increased product variety. Generally speaking, gains from trade result from the increase in competitive pressures as the domestic economy becomes less insulated from the world economy. Nonetheless, the numerous maket structures and firm behaviors pos. sible under imperfect competition preclude a definitive statement about the optimality of free trade. 


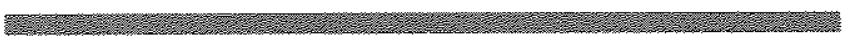

Figure 3

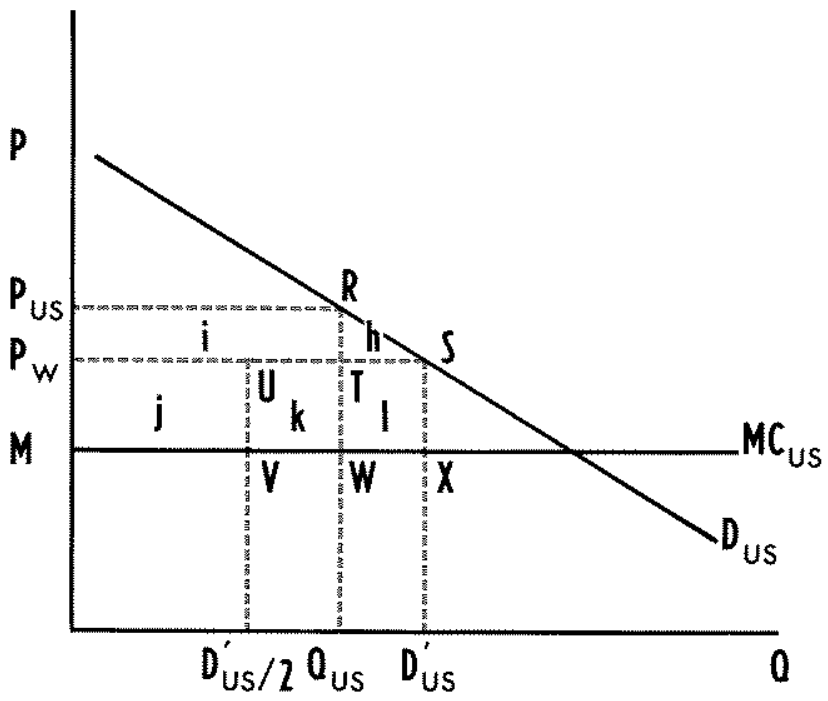

163

Sometimes the benefits of expanded consumption resulting from free trade are less than the costs associated with distorted production. Venables and Smith (1986) provide a graphical illustration, duplicated in figure 3 , of the preceding point using the BranderKrugman duopoly model. Assume the U.S. market and the market in the rest of the world for a specific good are monopolies, the good is produced at a constant marginal cost, and there are no transportation costs.
The demand curve is $D_{\mathrm{us}}$ and the marginal cost curve is $\mathrm{MC}_{\mathrm{us}}$ (The marginal revenue curve associated with $\mathrm{D}_{\mathrm{u}}$ is omited. The monopoly price and output are $P_{\text {us }}$ and $\mathrm{Q}_{\mathrm{un}}$

The change from autarchy to free trade transforms the national monopolies into a world duopoly. Assuming the firms follow a Coumot strategy, price declines from $P_{u s}$ to $P_{w}$ sales in the United States increase from $Q_{u s}$ to $D^{\prime}{ }_{u s s}$ and consumers gain area $P_{u s}$ RS $P_{w}$ or $h+i$. Profits (ignoring fixed costs) in the United States decline from area $P_{u s}$ RWM or $\mathbf{i}+\mathbf{i}+$ k to area $P_{w}$ SXM or $j \frac{-3}{3} k+1$. The domestic firm has onehalf of the domestic market, so its profits are $j$ with $k+$ 1 going to the foreign firm. The domestic firm's exports allow it to capture one-half of the foreign market. If the foreign market is identical to the domestic market the firm's profits on foreign sales will equal $k+1$. Therefore $_{*}$ the net reduction in the domestic firm's profits is $\mathrm{i}-\mathrm{I}$ and the overall welfare gain to the economy is $\mathrm{h}+\mathrm{l}$.

If the assumption of identically sized domestic and foreign markets is dropped, then a different conclusion is possible. If the foreign market is smaller than the domestic, the profts of the domestic firm in the foreign market will be less than $k+1$. Assuming zero exports, the domestic gains from trade are $h-k$, and the domestic economy could lose from free trade. In this case, consumer gains can be more than offset by the shifting of profits from the domestic to the foreign economy, This shifting reflects the contraction of an activity that is already too little to an even smaller level. 